\title{
Article \\ Religious Coping of Selected Filipino Catholic Youth
}

\author{
Fides del Castillo ${ }^{1, *}$ and Marie Antoniette Alino ${ }^{2}$ \\ 1 Theology and Religious Education Department, De La Salle University Manila, Manila 1004, Philippines \\ 2 General Education Department, St. Paul University Quezon City, Quezon City 1112, Philippines; \\ maalino@spuqc.edu.ph \\ * Correspondence: fides.delcastillo@dlsu.edu.ph; Tel.: +63-933-634-5460
}

Received: 15 August 2020; Accepted: 7 September 2020; Published: 9 September 2020

\begin{abstract}
This study determined the reliability and validity of the Brief Religious Coping Scale (Brief RCOPE) outside the Western Christian context. After construct and measurement equivalence, the Brief RCOPE was used to ascertain and illuminate the religious coping of selected Catholic youth in the Philippines. A group of students studying in Catholic universities $(n=335)$ completed the research measures. The findings of this study showed that the Brief RCOPE has good internal consistency and construct validity. However, the scale has two orthogonal factors. The results indicated that many Filipino Catholic youth used positive religious coping methods more frequently than negative strategies. In addition, the results suggest that Brief RCOPE may be useful to researchers interested in the religious coping of youth.
\end{abstract}

Keywords: religious coping; Catholic Church; Filipino; youth

\section{Introduction}

"Life is difficult. This universal truth once understood and accepted, allows us to transcend the challenges of daily living" (Peck 2002, p. 15). Life's difficulties lie on the "common hassles as well as the major trials of human existence: aging, catastrophic illness, or disability; family, social, and economic difficulties; the loss of loved ones; and confronting our death" (Hood et al. 2009, p. 472). There are no easy answers to the problems of life. However, we can cope with uncertainties and difficulties. "From its biological and evolutionary roots to complex human social behavior, coping is the essence of living" (Hood et al. 2009, p. 460). By utilizing a system of beliefs, practices, and relationships, human beings can negotiate stressful situations. One of these systems of beliefs and practices is religion. Koenig (2012) defines religion as that which:

Involves beliefs, practices, and rituals related to the transcendent, where the transcendent is God, Allah, HaShem, or a Higher Power in Western religious traditions, or to Brahman, manifestations of Brahman, Buddha, Dao, or ultimate truth/reality in Eastern traditions. This often involves the mystical or supernatural. Religions usually have specific beliefs about life after death and rules about conduct within a social group. Religion is a multidimensional construct that includes beliefs, behaviors, rituals, and ceremonies that may be held or practiced in private or public settings but are in some way derived from established traditions that developed over time within a community. (p. 3)

William James (1917), one of the founders of the psychology of religion, asserts that the religious field is divided into "institutional" and "personal" wherein the former "keeps the divinity" while the latter "keeps man most in view" (p. 30). Personal religion refers to "the feelings, acts, and experiences of individual men in their solitude, so far as they apprehend themselves to stand in relation to whatever they may consider the divine" (James 1917, pp. 31-32). Hood et al. (2009) explain that "personal 
religion is demonstrated by a person through prayer, reading of scriptures, and meditation" (p. 35). It is from the personal relationship of man with the divine that "theologies, philosophies, and ecclesiastical organizations [or institutional religion] may secondarily grow" (James 1917, p. 32). Institutional religion enables people who profess the same faith to worship the divine or sacred with other believers, participate in religious committees and receive, as well as provide, social support (Hood et al. 2009).

The constructive role of institutional religion can help the religious person to handle the common hassles of daily life as well as cope with adversity. The Catholic Church, one of the world's largest institutional religions with 1.3 billion baptized Catholics (Central Office of Church Statistics of the Secretariat of State 2017) teaches that "there will always be problems, always, and when we solve one, another one duly arrives. We can, however, find stability in Jesus. With him, joy abides in our hearts, hope is reborn, suffering is transformed into peace, fear changes into trust, and hardship is turned into an offering of love" (Francis 2017, para. 8). Since "suffering can upset life's most stable equilibrium; it can shake the firmest foundations of confidence, and sometimes even leads people to despair of the meaning and value of life. There are struggles that we cannot sustain alone, without the help of divine grace" (Benedict XVI 2008, para. 5). The Catholic Church teaches that divine grace comes from Jesus Christ. Hence, "the Church has to try to meet man in a special way on the path of his suffering" (John Paul II 1984, para. 3). It is "Christ who suffers with us, enabling us to share our pain with him. United to the suffering of Christ, human suffering becomes a means of salvation" (John Paul II 2003, para. 4).

The Catholic Church also teaches that some of the major trials of faith which can also cause moral suffering are "the danger of death, the death of one's children and, especially, the death of the firstborn and only son; the lack of offspring, nostalgia for the homeland, persecution, and hostility of the environment, mockery, and scorn of the one who suffers, loneliness and abandonment" (John Paul II 1984, para. 6). Acknowledging that the human person is a psychological and physical "whole", the Catholic Church also instructs believers that "moral sufferings have a physical or somatic element, and that they are often reflected in the state of the entire organism" (John Paul II 1984, para. 6).

Recent empirical studies in the psychology of religion highlight the connection between religion, spirituality, and health. Koenig (2012) reports that "research examining religion, spirituality, and health has been rapidly expanding-and most of it is occurring outside the field of psychiatry" (p. 2). Hundreds of quantitative original data-based research papers show that "religion/spirituality boost positive emotions and help neutralize negative emotions, hypothesizing that it serves as both a life-enhancing factor and as a coping resource. Religion/spirituality helps people to deal better with adversity, either external adversity (difficult environmental circumstances) or internal adversity (genetic predisposition or vulnerability to mental disorders)" (p. 4). Moreover, "people who are more religious/spiritual have better mental health and adapt more quickly to health problems compared to those who are less religious/spiritual. These possible benefits to mental health and well-being have physiological consequences that impact physical health, affect the risk of disease, and influence response to treatment" (p. 15).

\subsection{Religion as a Coping Resource}

While religion is usually associated with good health, both psychologically and physically (Koenig 2012; Hood et al. 2009; John Paul II 1984), "it is an overgeneralization to say that religion is necessarily good or bad for one's health" (Hood et al. 2009, p. 445). What research specifically determined, however, is that religion can aid a person to cope with the difficulties of life (Koenig 2012; Pargament et al. 2011; Belavich 1995). Religion, as a coping resource, helps a person "to understand and deal with life stressors" (Pargament et al. 2011, p. 52).

Koenig (2012), informed by numerous empirical studies on religion, spirituality, and health, asserts that religion "may increase the frequency of positive emotions and reduce the likelihood that stress will result in emotional disorders such as depression, anxiety disorder, suicide, and substance 
abuse. Religious coping resources include powerful cognitions (strongly held beliefs) that give meaning to difficult life circumstances and provide a sense of purpose." (p. 7).

Among religious people, one common way of using religion to cope with adversity is "collaboration with God." Pargament et al. (1988) describe collaborative coping: "When a person declares, 'God is my partner. He works with me and strengthens me', he or she makes known that the problem-solving process is held jointly by an individual and God. Hence, God and the person are active contributors and co-partners in the problem-solving process" (p. 92).

Interestingly, collaborative coping is taught by the Catholic Church by highlighting the primacy of God in the human-divine relationship and the issue of suffering: "From the beginning, Jesus associated his disciples with his own life, revealed the mystery of the Kingdom to them, and gave them a share in his mission, joy, and sufferings" (Catholic Church 1997, para. 787). Pope Francis (2017) explains:

We are tempted to always seek [solutions for] ourselves, brooding and sinking into anguish, licking our wounds, instead of going to [Jesus], who says, "Come to me, all who labour and are heavily laden, and I will give you rest", (Mt 11: 28). Let us not be held captive by the temptation to remain alone and discouraged, crying about what is happening to us. Let us not give in to the useless and inconclusive logic of fear, resignedly repeating that everything is going badly and nothing is as it once was. (para. 7)

\subsection{Religious Coping among Youth}

Current research on the psychology of religion informs us of the importance of religious coping among youth as they grapple with physical, psychological, and social problems.

In examining the relationship between post-traumatic stress (PTS) and religious coping among Israeli undergraduate students, Zukerman and Korn (2013) found out that the "tension existing between the exposure to a traumatic event and the previously held basic cognitions [of the students] can be attenuated by active religious coping that includes a constant reminder of the association between the individual and God" (p. 1688). In their study of depression among adolescents, Sarizadeh et al. (2020) discovered that "confidence, negative religious coping, positive religious coping, caring, connection, character, and gender are the predictors of depression." Hence, "attention should be paid to Positive Youth Development programmes and religious coping of adolescents to prevent and reduce depression" (Sarizadeh et al. 2020, p. 216). In a survey of low-income urban adolescents on their total exposure to urban stressors, Carleton et al. (2008) found out that religious coping resources may serve to interrupt the link between stress and depressive symptoms among selected adolescents. They assert that "the availability of particular religious coping resources, specifically spiritual support and community service opportunities, moderate the relationship between stress and depression among females, but not among males" (p. 118). In their investigation of the relationship between religiosity, spirituality, and youth violence, Salas-Wright et al. (2013) found out that "religious coping and spirituality have important implications in terms of the involvement of Salvadoran youth in violent behaviors. Religious coping and spirituality were both significantly associated with social developmental factors that, in turn, were associated with youth violence" (p. 187). In her survey of empirical studies on how youth use religious coping strategies to deal with different stressors such as parental divorce, parental death, sexual assault, and serious illness, Talik (2013) reported that "religious coping is relevant for the young, that is, positive religious coping correlates positively with indicators of adjustment (i.e., positive affect and life satisfaction) and negatively with indicators of psychological distress (i.e., negative affect and clinical symptomatology)" (p. 144).

Empirical studies on religious coping among youth have not been very popular in the Philippines. There has been a study on Catholic youth religiosity by Agoncillo (2015) but it focused on the level of religiosity of Filipino Catholic youth along the traditional lines of beliefs, practices, and attitudes. Hence, there was no mention of how Filipino Catholic youth utilize religion as a coping resource to deal with life stressors. One of the few research studies on the coping of Filipino youth was done by De Leon and Balila (2014) using the COPE Inventory developed by Carver et al. (1989). 
Results gathered from a group of Filipino college students revealed that many Filipino adolescents manage stressful situations by "finding support, using substances, planning on ways to solve the problem and acting on it, and by using humor" (p. 80).

\subsection{Faith, Culture, and Doctrine: Coping Resources for Filipino Catholics}

The Catholic Church teaches that "Christianity is the religion of the Word of God", a word which is not a written and mute word, but the incarnate Word and living" (Catholic Church 1997, para. 108). "It must be stressed however that many Catholics are not simply defined as 'people of the book'. They are followers of the incarnate Word of God which is Jesus Christ. This personal relationship with Jesus Christ (which encompasses the moral, physical, and spiritual domains) is one of the sources of the Christian life" (del Castillo et al. 2020, para. 2). Catholic Church (1997) also teaches that those who believe in the Catholic faith are "incorporated into the Church through the sacrament of baptism and become sharers in the mission" (para. 1213).

A critical survey of the Christianization of the Philippines shows that the Catholic Church grew from the personal religion of the indigenous people (del Castillo 2018). "Before the arrival of the Spanish Catholic missionaries on the Philippine archipelago, the indigenous people already had a worldview and religion of their own. Despite numerous challenges on evangelization, the Catholic missionaries succeeded. The Catholic Church thrived in the Philippines and became the dominant religion" (del Castillo 2018, p. 3). In one of his messages to Filipino Catholics, John Paul II (1981) said:

The Philippine nation is deserving of particular honor since, from the beginning of its Christianization, from the moment that Magellan planted the Cross in Cebu [province] on 15 April 1521, all through the centuries, its people have remained true to the Christian faith. In an achievement that remains unparalleled in history, the message of Christ took root in the hearts of the people within a very brief period, and the Church was thus strongly implanted in this nation of seven thousand islands and numerous tribal and ethnic communities. (para. 2)

As of 2017, there are around 80 million Filipino Catholics in a country of 101 million people (Philippine Statistics Authority 2017). However, De Mesa (1998) observed that the form of Catholicism in the country is Roman Catholicism. Historical records show that "the Philippines had been evangelized from Europe at a time when the classical understanding of culture was predominant. As a result, the evangelization handed on to Filipinos was the Western European-North American form of Roman Catholicism. However, Roman Catholicism is just one of the many different ways to express Catholicism" (De Mesa 1998, p. 192). John Paul II (1981), in his pastoral visit to the Philippines, acknowledged the importance of culture in the practice of faith, "The rich geographical and human diversity, the various cultural traditions, and the people's spirit of joy and sharing, together with the fruits of the missionary efforts, have successfully blended and have shaped a clear national identity that is unmistakably Filipino and truly Christian" (para. 2).

As for the intimate link between culture and faith demonstrated in Filipino Catholic religious expressions, Pope Francis (2015) said:

Filipino culture has been shaped by the imagination of faith. Filipinos everywhere are known for their love of God, their fervent piety, and their warm devotion to Our Lady and her rosary. This great heritage contains a powerful missionary potential. It is how [the Filipino] people have inculturated the Gospel and continue to embrace it. (para. 8)

Acknowledging the necessity of an inculturated Catechism, the Episcopal Conference of the Philippines created the Catechism for Filipino Catholics (CFC). It is "a catechism that is specifically written for Filipinos that responds to the concrete situation and culture of Filipino Catholics and families today, in terms of Filipino culture and values" (Catholic Church Bishop's Conference of the Philippines 1997, para. 6). The CFC (which was granted approbation by the Congregation for the Doctrine of the Faith) can serve as a "reliable Catholic word, especially in family and youth catechesis. 
It instructs believers about Christian moral values and teaches the Catholic tradition of community worship" (Catholic Church Bishop's Conference of the Philippines 1997, para. 9). More importantly, it highlights the "mutual interaction of the Judaeo-Christian tradition and the Filipino Catholic's present-day experiences or culture. It interprets the Filipino people's relationship with God through the instrumentality of their culture" (De Mesa 1998, p. 199).

As "an instrument for creatively handing on the Catholic Faith to Filipinos" (Catholic Church Bishop's Conference of the Philippines 1997, para. 3), the CFC instructs believers about sufferings in life. Central to these teachings is that "Jesus can identify with us in our poverty, sufferings, and oppression" (para. 553). Additionally, "God our Father is concerned precisely with every one of us, here and now, in all our troubles and sufferings" (para. 291). The Catholic Church also teaches that "God's providence offers the believing Christian the spiritual strength and hope needed to face suffering and refuse to be overcome by them" (Catholic Church Bishop's Conference of the Philippines 1997, para. 346). As for the mystery of evil and suffering, the CFC teaches that "sin is the result of our free choice of evil" (para. 291).

The doctrines of the Catholic Church can serve as cognitive strategies for baptized Catholics to cope with suffering. Faith, culture, and doctrine serve as coping resources for Filipino Catholics to grapple with the major trials of human existence such as catastrophic illness or disability, loss of a family member or relative, severe financial difficulties, loneliness, and abandonment. Francis (2013) explains:

The light of faith does not make us forget the sufferings of this world. [ ... ] Faith is not a light which scatters all our darkness, but a lamp which guides our steps in the night and suffices for the journey. To those who suffer, God does not provide arguments which explain everything; rather, his response is that of an accompanying presence, a history of goodness which touches every story of suffering and opens up a ray of light. (para. 57)

Hence, we assert that the Catholic religion, especially the inculturated doctrines of the Church on the mystery of evil and suffering (Catholic Church 1997; John Paul II 1984; Benedict XVI 2008), can serve as cognitive strategies for many Filipino Catholics to cope, adapt, and respond to events that "try men's souls".

There are very few empirical studies on the link between religion, spirituality, and health in the Philippines. Cruz et al. (2017) evaluated the psychometric properties of the Filipino versions of the Duke University Religion Index (DUREL-F) and the Spiritual Coping Strategies scale (SCS-F) for hemodialysis patients in the Philippines. They discovered that

as the respondents get older, their participation in religious practices, such as attending church, Bible study and praying, becomes more frequent and their personal religious commitment and motivation become stronger. Older people often consider religious activities as their most common social activity as well as their most significant factor that support them to cope with physical health problems (p. 1392)

Shedding light on how Filipinos cope with stressful situations, the Filipino Coping Strategies Scale developed by Rilveria (2018) revealed that many Filipinos deal with negative life events through cognitive reappraisal, social support, problem-solving religiosity, tolerance, emotional release, overactivity, relaxation/recreation, and substance use.

\subsection{The Religiosity of the Filipino Catholic Youth}

Filipino youth, as stipulated in Republic Act 8044, refers to "those persons whose ages range from fifteen (15) to thirty (30) years old" (Youth in Nation Building Act 1995, sec. 4). Based on data from the Philippine Statistics Authority (2017),

the total population of the country was at $100,981,484$, wherein $29.31 \%$ belonged to the 15 to 30 age brackets. The younger cohort (15 to 22 years old) of the population was at 15.9 million 
and the older cohort ( 23 to 30 years old) was at 13.6 million. The male youth was at $14.92 \%$ and the female youth was at $14.40 \%$ of the total country population (Arceo 2018, p. 1)

Acknowledging the significant number of young people in the Philippines, the Catholic Church Bishop's Conference of the Philippines (1992) considers the Philippines as "the country of the young". "The CBCP also recognizes the youth as the Church's greatest resource for evangelization" (Agoncillo 2015, p. 127).

The study by Agoncillo (2015) on Filipino Catholic religiosity describes Filipino Catholic youth as:

Having moderate knowledge of Catholic doctrine. They can explain their views to a moderate extent only. In terms of morals, Filipino Catholic youth hold beliefs that are moderately consistent with what the Catholic Church teaches. In terms of practices, they go to Mass at least once a week, pray the Rosary regularly, and visit the Blessed Sacrament often. Going to confession is done less frequently, about a few times a year. Personal prayer is done several times a day. The Filipino Catholic youth strongly feel the presence of God in their lives and they have had religious experiences that indicate this presence. (p. 132)

Informed by the results of their study on the configurations of student religiosity/spirituality of selected Filipino youth, Baring et al. (2016) concluded, "Religiosity/spirituality is a probable factor for psychosocial adjustment. Higher levels of religiosity/spirituality contribute to more satisfying relationships, more academic success, greater well-being, and greater civic engagement (social capital)" (p. 172).

\section{Measuring the Religious Coping of Filipino Catholic Youth}

In 2014, the Catholic Bishops Conference of the Philippines-Episcopal Commission on the Youth (CBCP-EPC) surveyed 13 to 22-year-old students from Catholic private schools and state-run institutions nationwide. The study formed "baseline data for population profile regarding religion. However, it failed to investigate the underlying dimensions that characterize the respondent's notions of religion" (Baring et al. 2018, p. 85). While "the directions of local scholarship in youth research generally show robust descriptions of students' religious orientations" (Baring 2018, p. 387), there is a scarcity of studies on religious coping among Filipino Catholic youth. Despite the majority of Filipinos professing the Catholic faith, it seems that religious coping was not given much attention. This mirrors Pargament's (1997) observation that "general coping theorists and researchers neglected the religious dimension for the most part." In this paper, the researchers would like to address the gap in knowledge and investigate the religious coping of Filipino Catholic youth.

Since there is no culturally adapted scale to measure the religious coping of Filipino Catholic youth, the researchers communicated with Kenneth I. Pargament who permitted the use of the Brief Religious Coping Scale (Brief RCOPE). Pargament et al. (2011) describe the Brief RCOPE as "a 14-item measure of religious coping with major life stressors. It has demonstrated its utility as an instrument for research and practice in the psychology of religion and spirituality" (p. 51). However, Pargament et al. (2011) also acknowledge that "more studies are needed to determine the extent to which the Brief RCOPE is useful in cultures outside of the Western, largely Christian context" (p. 76).

This paper answers the following questions. (1) Is the Brief RCOPE reliable and valid in the Filipino context? (2) How does the Brief RCOPE illumine the religious coping of Filipino Catholic youth?

\subsection{Method}

As a cross-cultural study, the researchers carefully considered the construct equivalence of the Brief RCOPE. The theoretical construct that is measured by the Brief RCOPE is religious coping strategies. Religion, according to Pargament, "is conceptualized as systems of significance that are grounded in beliefs about the sacred (individual aspect) and is realized within broader religious context (institutional)" (Talik 2013, p. 146). The individual and institutional aspects of religion are present in Filipino Catholic psychology of religion. Moreover, the main functions of religion 
identified by Pargament et al. (2000) are consistent across both cultures: religion plays a key role in searching for meaning (Catholic Church Bishop's Conference of the Philippines 1997; Nakonz and Shik 2009) and sense of life (Catholic Church Bishop's Conference of the Philippines 1997; Nakonz and Shik 2009). Religion also can be a source of comfort and closeness to God (Catholic Church Bishop's Conference of the Philippines 1997; Hechanova et al. 2015) and to other people (Catholic Church Bishop's Conference of the Philippines 1997; Hechanova and Waelde 2017). Religion also releases one from feeling guilty (Catholic Church Bishop's Conference of the Philippines 1997). There are many similarities in behaviors associated with the theoretical construct across both cultures such as God's abiding presence during our difficult moments (Catholic Church Bishop's Conference of the Philippines 1997; Rilveria 2018), collaboration with God in problem-solving (Catholic Church Bishop's Conference of the Philippines 1997), and asking for God's help (Catholic Church Bishop's Conference of the Philippines 1997; Rilveria 2018).

However, one religious coping strategy that seems more specific for the Western culture than Filipino is "decided the devil made this happen." The Catholic Church Bishop's Conference of the Philippines (1997) explicitly states: “The power of the 'fallen angel' is limited by the providence of God who makes all things work together for the good of those who have been called according to his purpose" (para. 68). As for religious coping of religiously oriented Filipinos, Captari et al. (2018) found out that those who employ negative religious coping experienced higher levels of emotional exhaustion and depersonalization.

The construct equivalence of the Brief RCOPE for Filipino Catholics has been positively verified. The behaviors associated with the theoretical construct are similar between the source and target culture.

\subsection{Participants}

A total of 335 Filipino Catholic College students (62\% females, 38\% males) participated in the present study. The mean age of the respondents is 20.33 years, with a standard deviation of 2.47 years. Most of the participants identified academic problems $(n=137$ or $40.9 \%)$ as major stressors while others identified financial difficulties $(n=55$ or $16.42 \%)$, problems with family relationships ( $n=52$ or $15.52 \%)$, loss of a family member or relative ( $n=42$ or $12.54 \%$ ), and romantic breakdown ( $n=22$ or $6.57 \%$ ) as stressors. A small part of respondents feel that issues of psychological well-being ( $n=8$ or $2.39 \%)$, COVID-19 pandemic related issues $(n=5$ or $1.49 \%$ ), self-related issues $(n=5$ or $1.49 \%)$, regrets from past decisions and failures $(n=2$ or $0.6 \%)$, and catastrophic illness or disability ( $n=2$ or $0.6 \%)$ as major stressors. A few participants find themselves stressing over two or more factors like loss of relatives, financial difficulties, and family relationship ( $n=2$ or $0.6 \%$ ); romantic breakdown and academic problems ( $n=1$ or $0.3 \%$ ); family relationships and academic problems ( $n=1$ or $0.3 \%$ ); and illness and loss of a family member $(n=1$ or $0.3 \%$ ).

The youth who participated in the survey claimed to believe in God and the majority of them report that they communicate with God through personal prayers. Most of the informants participate in and receive the Sacrament of the Holy Eucharist. As students in Catholic universities, the informants also study religion courses and attend annual spiritual retreats offered by their educational institutions.

\subsection{Instrument}

Filipino Catholic college students' religious coping practices were measured using the Brief Religious Coping Scale (RCOPE) (Pargament et al. 1998). The Brief RCOPE has two subscales that measure positive and negative religious coping mechanisms. The positive items were generated from the seven subscales of the original RCOPE: spiritual connection, seeking spiritual support, religious forgiveness, collaborative religious coping, benevolent religious reappraisal, religious purification, and religious focus. The seven negative items were extracted from five subscales of the original RCOPE: spiritual discontent, punishing God reappraisal, interpersonal religious discontent, demonic reappraisal, and reappraisal of God's power (Pargament et al. 1998). Its subscales, sample items, and the number of items per subscales are shown in Table 1 . The Brief 
RCOPE uses a 4-point positively packed agreement rating scale (not at all, somewhat, quite a bit, a great deal) which is appropriate when respondents are likely to hold positive attitudes towards the construct being measured.

Table 1. Religious Coping Scale (RCOPE) Subscales and Sample Items.

\begin{tabular}{ccc}
\hline Factors & Sample Item & Number of Items \\
\hline Positive Religious Coping & Look for a stronger connection with God. & 7 \\
Negative Religious Coping & Wondered whether God had abandoned me. & 7 \\
\hline
\end{tabular}

\section{Results}

Means and standard deviations were calculated for the two subscales of the Brief RCOPE as shown in Table 2. Positive religious coping has a mean score of 2.82, while negative religious coping has a mean score of 1.70. The standard deviations show a minimum dispersion of scores from the mean of each subscale. Measures of skewness and kurtosis were also computed to provide more information about how the subscale scores were distributed. The positive religious coping subscale obtained a skewness measure of -0.54 ; this indicates that the distribution is slightly skewed. The negative religious coping subscale has a skewness measure of 1.70 which indicates that the distribution is moderately skewed. Positive religious coping subscale has a kurtosis value of -0.69 , while the negative religious coping subscale has 1.24. A positive kurtosis value indicates that the distribution is leptokurtic (i.e., more peaked than the normal distribution and has fatter tails) and a negative kurtosis value indicates that the distribution is platykurtic (i.e., has lighter tails and a flatter peak than the normal distribution). Cronbach's alpha values were also calculated for each of the subscales to establish internal consistency reliability. A scale has good internal consistency if it has obtained a Cronbach's alpha value of 0.70.

Table 2. Brief RCOPE Mean, Standard Deviation, Skewness, Kurtosis, and Cronbach's $\alpha$.

\begin{tabular}{|c|c|c|c|c|c|}
\hline \multicolumn{6}{|l|}{$n=335$} \\
\hline Subscales & $\mathbf{M}$ & SD & Skewness & Kurtosis & Cronbach's $\alpha$ \\
\hline Positive Religious Coping & 2.82 & 0.86 & -0.54 & -0.69 & 0.93 \\
\hline 1. Looked for a stronger connection with God. & 2.90 & 1.03 & & & \\
\hline 2. Sought God's love and care. & 3.00 & 1.00 & & & \\
\hline 3. Sought help from God in letting go of my anger. & 2.84 & 1.09 & & & \\
\hline 4. Tried to put my plans into action together with God. & 2.79 & 1.03 & & & \\
\hline $\begin{array}{l}\text { 5. Tried to see how God might be trying to strengthen me in } \\
\text { this situation. }\end{array}$ & 3.01 & 0.99 & & & \\
\hline 6. Asked forgiveness for my sins. & 3.07 & 1.02 & & & \\
\hline 7. Focused on religion to stop worrying about my problems. & 2.13 & 0.98 & & & \\
\hline Negative Religious Coping & 1.70 & 0.69 & 1.20 & 1.24 & 0.86 \\
\hline 8. Wondered whether God had abandoned me. & 1.94 & 1.02 & & & \\
\hline 9. Felt punished by God for my lack of devotion. & 1.93 & 1.01 & & & \\
\hline 10. Wondered what I did for God to punish me. & 1.96 & 1.03 & & & \\
\hline 11. Questioned God's love for me. & 1.70 & 0.94 & & & \\
\hline 12. Wondered whether my church had abandoned me. & 1.42 & 0.82 & & & \\
\hline 13. Decided the devil made this happen. & 1.41 & 0.78 & & & \\
\hline 14. Questioned the power of God. & 1.53 & 0.87 & & & \\
\hline
\end{tabular}

Confirmatory factor analysis (CFA) utilizing TIBCO Statistica software was used to test Pargament et al. (1998) original two-factor model. The following fit indices and criteria were used to establish model fit: chi-square index is statistically non-significant; the root mean square error of approximation (RMSEA) is 0.06 or less for a close fit, 0.08 for fair fit, and 0.10 for marginal fit; the comparative fit index (CFI), the adjusted goodness of fit index (AGFI), and the goodness of fit index (GFI) are at least 0.90 to indicate good fit between a model and the data (Browne and Cudeck 1993).

Although the chi-square test was significant, $\chi^{2}=3034.879, p<0.05$, the CFI of 0.92 indicates a good fit. The model yielded acceptable goodness of fit indices (0.88 and 0.84$)$ for both the GFI and AGFI, respectively. The RMSEA of 0.097 is an indicator of marginal fit. Table 3 shows that all of 
the items in Pargament et al. (1998) Brief RCOPE loaded significantly on their hypothesized factor $(p<0.05)$, except for one item under Negative Religious Coping (i.e., Decided the devil made this happen.) which had non-significant factor loadings. This item had standardized factor loadings below 0.4 , which indicates that the item appears to be unrelated to the underlying dimension it is supposed to measure.

Table 3. RCOPE Factor Loadings, Standard Error, and T-statistics.

\begin{tabular}{|c|c|c|c|}
\hline Factors and Statements & $\begin{array}{c}\text { Standardized } \\
\text { Factor Loading }\end{array}$ & $\begin{array}{l}\text { Standard } \\
\text { Error }\end{array}$ & $\mathrm{T}$ \\
\hline \multicolumn{4}{|l|}{ Positive Religious Coping } \\
\hline 1. Looked for a stronger connection with God. & 0.93 * & 0.044 & 21.05 \\
\hline 2. Sought God's love and care. & $0.88 *$ & 0.043 & 20.16 \\
\hline 3. Sought help from God in letting go of my anger. & $0.87 *$ & 0.05 & 17.45 \\
\hline 4. Tried to put my plans into action together with God. & $0.9 *$ & 0.045 & 20.2 \\
\hline 5. Tried to see how God might be trying to strengthen me in this situation. & $0.81 *$ & 0.045 & 18.1 \\
\hline 6. Asked forgiveness for my sins. & $0.73 *$ & 0.049 & 15.02 \\
\hline 7. Focused on religion to stop worrying about my problems. & $0.71 *$ & 0.047 & 15.03 \\
\hline \multicolumn{4}{|l|}{ Negative Religious Coping } \\
\hline 8. Wondered whether God had abandoned me. & $0.81 *$ & 0.048 & 16.82 \\
\hline 9. Felt punished by God for my lack of devotion. & $0.71 *$ & 0.05 & 14.05 \\
\hline 10. Wondered what I did for God to punish me. & $0.79 *$ & 0.049 & 15.97 \\
\hline 11. Questioned God's love for me. & $0.78 *$ & 0.043 & 17.95 \\
\hline 12. Wondered whether my church had abandoned me. & 0.54 * & 0.041 & 13.11 \\
\hline 13. Decided the devil made this happen. & 0.32 & 0.043 & 7.433 \\
\hline 14. Questioned the power of God. & $0.55^{*}$ & 0.045 & 12.26 \\
\hline
\end{tabular}

Note: ${ }^{*} p<0.05$.

The correlation between positive religious coping and negative religious coping was also measured as shown in Table 4. The results show that the scale has two uncorrelated or orthogonal factors. It does not support divergent validity or concurrent validity.

Table 4. Correlation Matrix.

\begin{tabular}{lc}
\hline & Positive Religious Coping \\
\hline Negative Religious Coping & 0.052 \\
\hline
\end{tabular}

The positive religious coping and negative religious coping subscales were also subjected to a paired T-test to compare the scores of the two subscales as shown in Table 5. The results show that there is a significant difference between the positive religious coping and negative religious coping mean scores of Filipino Catholic youth. The respondents' scores in positive religious coping are statistically higher than their negative religious coping scores.

Table 5. Paired T-test Results.

\begin{tabular}{ccc}
\hline & Values & Interpretation \\
\hline Means & & \\
Positive Religious Coping & 2.82 & Reject Ho, Accept Ha \\
$\begin{array}{c}\text { Negative Religious Coping } \\
\text { t Statistic }\end{array}$ & 1.75 & \\
\hline \multicolumn{3}{c}{$17.64 *$} \\
Note: ${ }^{*} p<0.05$.
\end{tabular}

\section{Discussion}

The results of the construct and measurement equivalence show that the Brief RCOPE had good internal consistency and construct validity. The confirmatory factor analysis (CFA) revealed that the model yielded acceptable goodness of fit indices. However, item \#13 "Decided the devil made this happen" showed a very low factor load which supports the assertion of the researchers that 
it is a religious coping strategy more specific for the Western culture than Filipino. Interestingly, the correlation matrix between positive religious coping (PRC) and negative religious coping (NRC) demonstrated that the scale has two uncorrelated or orthogonal factors. This confirms the findings of Pargament et al. (2011) that "the majority of studies have found that the PRC and NRC scales are not significantly associated with each other" (p. 72). In addition, the significant difference between the PRC and NRC mean scores prove that many Filipino Catholic youth favor PRC to manage major life stressors. This supports the findings of Pargament et al. (2011), "Normative data show that respondents on average report relatively low levels of negative religious coping and relatively high levels of positive religious coping. Studies also indicate that non-whites generally tend to have higher PRC scores and lower NRC scores than whites" (p. 72).

\section{Conclusions}

This study contributes to the discussion on the intimate link between religion and health, the utility of the Brief RCOPE outside the Western Christian context, and religious coping of Filipino Catholics.

Religion can serve as an important resource for coping and also contribute to positive mental health. While "the Brief RCOPE does not offer an extensive or intensive look into the many methods of religious coping" (Pargament et al. 2011, p. 72), it illumined the religious coping of selected Filipino Catholic youth. The results of the study showed that many Filipino Catholic youth consider academic problems, financial difficulties, problems with family relationships, death of a family member or relative, and romantic breakdown as major life stressors. These stressors are also "major trials of faith" which cause moral and physical suffering (John Paul II 1984; Benedict XVI 2008; Francis 2017). However, there are many Filipino Catholic youth who utilize religion as a coping resource. Informed by the teachings of the Catholic Church on human suffering (Catholic Church Bishop's Conference of the Philippines 1997), many Filipino Catholic youth employ a pattern of positive religious coping. During times that "try men's souls", most of the Filipino Catholic youth "ask God for the forgiveness of sins", "try to see how God might be trying to strengthen them in the situation", "seek for God's love and care", and "look for a stronger connection with God". Hence, we assert that many Filipino Catholic youth have a deep sense of spirituality, enjoy a secure relationship with God, believe that there is meaning to be found in life, and maintain a sense of spiritual connectedness with others.

Overall, the findings of this study may help counselors, clinicians, educators, and researchers to understand better the coping strategies of Filipino Catholic youth.

Author Contributions: Conceptualization, F.d.C.; Methodology, M.A.A.; Software, M.A.A.; Validation, M.A.A.; Formal Analysis, M.A.A.; Investigation, F.d.C.; Resources, F.d.C.; Data Curation, F.d.C. and M.A.A.; Writing-Original Draft Preparation, F.d.C. and M.A.A.; Writing-Review and Editing, F.d.C. and M.A.A.; Project Administration, F.d.C. All authors have read and agreed to the published version of the manuscript.

Funding: This research received no external funding.

Acknowledgments: We wish to acknowledge the following: (1) Kenneth Pargament for providing the researchers with the Brief RCOPE, (2) De La Salle University Manila for the administrative support, and (3) Clarence Darro del Castillo for the technical support.

Conflicts of Interest: The authors declare no conflict of interest.

\section{References}

Agoncillo, Roland. 2015. Understanding Catholic Youth Religiosity in a Developing Country. Available online: https://icsai.org/procarch/1iclehi/1iclehi-47.pdf (accessed on 1 July 2020).

Arceo, Carlo John. 2018. Situation of the Filipino Youth and Students. Preprint. [CrossRef]

Baring, Rito. 2018. Emerging Transitions in the Meaning of Religious Constructs: The Case of the Philippines. Religions 9: 387. [CrossRef]

Baring, Rito, Romeo Lee, Madelene Maria, and Yan Liu. 2016. Configurations of Student Spirituality/Religiosity: Evidence from a Philippine University. International Journal of Children's Spirituality 1-14. [CrossRef] 
Baring, Rito, Philip Joseph Sarmiento, Nestor Sibug, Paolo Lumanlan, Benito Bonus, Cristina Samia, and Stephen Reysen. 2018. Filipino College Students' Attitudes towards Religion: An Analysis of the Underlying Factors. Religions 9: 85. [CrossRef]

Belavich, Timothy. 1995. The Role of Religion in Coping with Daily Hassles. New York: American Psychological Association. Benedict XVI. 2008. Apostolic Journey of His Holiness Benedict XVI to France on the Occasion of the 150th Anniversary of the Apparitions of The Blessed Virgin Mary at Lourdes. September 12-15. Available online: http://w2.vatican.va/content/benedict-xvi/en/homilies/2008/documents/hf_ben-xvi_hom_20080915_ lourdes-malati.html (accessed on 1 August 2020).

Browne, Michael, and Robert Cudeck. 1993. Alternative ways of accessing model fit. In Testing Structural Equation Models. Edited by Kenneth A. Bollen and Scott Long. Newbury Park: SAGE, pp. 136-62.

Captari, Laura, Joshua Hook, David Mosher, David Boan, Jamie Aten, Don Davis, Edward Davis, and Daryl Van Tongeren. 2018. Negative religious coping and burnout among national humanitarian aid workers following Typhoon Haiyan. Journal of Psychology and Christianity 37: 28-42.

Carleton, Rusell, Patricia Esparza, Peter Thaxter, and Kathryn Grant. 2008. Stress, Religious Coping Resources, and Depressive Symptoms in an Urban Adolescent Sample. Journal for the Scientific Study of Religion 47. [CrossRef]

Carver, Charles, Michael Scheier, and Jagdish Weintraub. 1989. Assessing coping strategies: A theoretically based approach. Journal of Personality and Social Psychology 56: 267-83. [CrossRef]

Catholic Church Bishop's Conference of the Philippines. 1992. Acts and decrees of the Second Plenary Council of the Philippines. Manila: The Philippines.

Catholic Church. 1997. Catechism of the Catholic Church, 2nd ed. Vatican City: Libreria Editrice Vaticana.

Catholic Church Bishop's Conference of the Philippines. 1997. Catechism for Filipino Catholics. Manila: ECCCE Word and Life Publications.

Central Office of Church Statistics of the Secretariat of State. 2017. The Pontifical Yearbook 2017 and the "Annuarium Statisticum Ecclesiae" 2015. Available online: https://press.vatican.va/content/salastampa/en/ bollettino/pubblico/2017/04/06/170406e.html (accessed on 1 August 2020).

Cruz, Jonas, Ralph Reyes, Paolo Colet, Joel Estacio, Silvia Caldeira, Luciano Vitorino, and Harold Koenig. 2017. Psychometric Evaluation of the Filipino Versions of the Duke University Religion Index and the Spiritual Coping Strategies Scale in Filipino Hemodialysis Patients. Journal of Religion and Health 56. [CrossRef]

De Leon, Jezamine, and Edwin Balila. 2014. Filipino adolescents' coping strategies: A confirmatory factor analysis. Adventist University of the Philippines Research Journal 18: 73-81. Available online: http://www.aup.edu.ph/ alumni/wp-content/uploads/R7.pdf (accessed on 20 July 2020).

De Mesa, Jose. 1998. Tasks in the Inculturation of Theology: The Filipino Catholic Situation. Missiology 26: 191-200. [CrossRef]

del Castillo, Fides. 2018. Perspectives on faith and culture in the Philippines, East Timor, and Indonesia. The International Journal of Civic, Political, and Community Studies 16: 1-11. [CrossRef]

del Castillo, Fides, Clarence Darro del Castillo, and Maricris Alvarez. 2020. Spiritual Well-Being and Its Role on the Sociality of Selected Catholic Religious Novices. Religions 11: 371. [CrossRef]

Francis. 2013. Lumen Fidei. Available online: http:/www.vatican.va/content/francesco/en/encyclicals/documents/ papa-francesco_20130629_enciclica-lumen-fidei.html (accessed on 30 July 2020).

Francis. 2015. Homily of Pope Francis. Mass with Bishops, Priests and Religious. Manila's Cathedral of the Immaculate Conception. Available online: https://globalnation.inquirer.net/117482/homily-of-pope-francisin-manila-cathedral (accessed on 1 July 2020).

Francis. 2017. Homily of his holiness Pope Francis. Available online: http://w2.vatican.va/content/francesco/ en/homilies/2017/documents/papa-francesco_20170402_omelia-visitapastorale-carpi.html (accessed on 30 July 2020).

Hechanova, Regina, and Lynn Waelde. 2017. The influence of culture on disaster mental health and psychosocial support interventions in Southeast Asia, Mental Health. Religion E Culture 20: 31-44. [CrossRef]

Hechanova, Regina, Pia Anna Ramos, and Lynn Waelde. 2015. Group-based mindfulness-informed psychological first aid after Typhoon Haiyan. Disaster Prevention and Management: An International Journal 24: 610-18. [CrossRef]

Hood, Ralph, Peter Hill, and Bernard Spilka. 2009. Psychology of Religion, 4th ed. New York: Guilford Press. 
James, William. 1917. The Varieties of Religious Experience: A Study in Human Nature. Being the Gifford Lectures on Natural Religion. New York: Longmans, Green, and Co.

John Paul II. 1981. Message of His Holiness John Paul II to the President and the People of the Philippines. Available online: http://www.vatican.va/content/john-paul-ii/en/speeches/1981/february/documents/hf_jpii_spe_19810217_manila-presidente.html (accessed on 1 August 2020).

John Paul II. 1984. Salvifici Doloris. On the Christian Meaning of Human Suffering. Available online: http://www.vatican.va/content/john-paul-ii/en/apost_letters/1984/documents/hf_jp-ii_apl_11021984_ salvifici-doloris.html (accessed on 30 July 2020).

John Paul II. 2003. Message of His Holiness John Paul II for the 12th World Day of the Sick. Available online: https:/www.vatican.va/content/john-paul-ii/en/messages/sick/documents/hf_jp-ii_mes_ 20031203_world-day-of-the-sick-2004.html (accessed on 1 August 2020).

Koenig, Harold. 2012. Religion, Spirituality, and Health: The Research and Clinical Implications. ISRN Psychiatry 2012: 278730. [CrossRef] [PubMed]

Nakonz, Jonas, and Angela Shik. 2009. And all your problems are gone: Religious coping strategies among Philippine migrant workers in Hong Kong. Mental Health, Religion E Culture 12: 25-38. [CrossRef]

Pargament, Kenneth. 1997. The Psychology of Religion and Coping. New York: Guilford Press.

Pargament, Kenneth, Joseph Kennell, William Hathaway, Nancy Grevengoed, Jon Newman, and Wendy Jones. 1988. Religion and the problem-solving process: Three styles of coping. Journal for the Scientific Study of Religion 27: 90-104. [CrossRef]

Pargament, Kenneth, Bruce Smith, Harold Koenig, and Lisa Perez. 1998. Patterns of positive and negative religious coping with major life stressors. Journal for the Scientific Study of Religion 37: 711-25. [CrossRef]

Pargament, Kenneth, Harold Koenig, and Lisa Perez. 2000. The many methods of religious coping: Development and initial validation of the RCOPE. Journal of Clinical Psychology 56: 519-44. [CrossRef]

Pargament, Kenneth, Margaret Feuille, and Donna Burdzy. 2011. The Brief RCOPE: Current Psychometric Status of a Short Measure of Religious Coping. Religions 2: 51-76. [CrossRef]

Peck, Scott. 2002. The Road Less Traveled, 25th Anniversary Edition: A New Psychology of Love, Traditional Values, and Spiritual Growth. New York: Simon and Schuster.

Philippine Statistics Authority. 2017. Results from the 2015 Census of Population. Available online: https: //psa.gov.ph/population-and-housing/node/120080 (accessed on 25 July 2020).

Rilveria, John Robert. 2018. The development of the Filipino coping strategies scale. Asia-Pacific Social Science Review 18: 111-26.

Salas-Wright, Christopher, Rene Olate, Michael Vaughn, and Thanh Tran. 2013. Direct and mediated associations between religious coping, spirituality, and youth violence in El Salvador. Revista Panamericana de Salud Publica = Pan American Journal of Public Health 34: 183-89.

Sarizadeh, Mohammad, Mahmoud Najafi, and Ali Mohammad Rezaei. 2020. The prediction of depression based on religious coping and the components of positive youth development in adolescents. Mental Health, Religion \& Culture 23: 1-13. [CrossRef]

Talik, Elizabeth. 2013. The adolescent Religious Coping Questionnaire. Translation and cultural adaptation of Pargament's RCOPE Scale for Polish adolescents. Journal of Religion and Health 52: 143-58. [CrossRef] [PubMed]

Youth in Nation Building Act. 1995. Available online: http://nyc.gov.ph/republic-act-8044/ (accessed on 1 August 2020).

Zukerman, Gil, and Liat Korn. 2013. Post-Traumatic Stress and World Assumptions: The Effects of Religious Coping. Journal of Religion and Health 53. [CrossRef] [PubMed]

(C) 2020 by the authors. Licensee MDPI, Basel, Switzerland. This article is an open access article distributed under the terms and conditions of the Creative Commons Attribution (CC BY) license (http://creativecommons.org/licenses/by/4.0/). 